P-ISSN: 2615-7586, E-ISSN: 2620-5556

Volume 3, Nomor 2, Desember 2020

licensed under a Creative Commons Attribution 4.0 International License http://publishing-widyagama.ac.id/ejournal-v2/index.php/yuridika/

\title{
MEMAHAMI PERAN LEMBAGA PEMBIAYAAN SYARI'AH DALAM MENINGKATKAN AKSESIBILITAS KEUANGAN UMKM PADA MASA \\ PANDEMI COVID19
}

\section{Misbahul Ilham¹, Iswi Hariyani²}

${ }^{1}$ Fakultas Hukum, Universitas Jember, email: bundaiswi62.fh@,unej.ac.id

${ }^{2}$ Fakultas Hukum, Universitas Jember

\begin{abstract}
ABSTRAK
Tulisan ini bertujuan untuk membahas mengenai kemampuan lembaga keuangan syariah untuk mengakomodir pembiayaan UMKM melalui Peraturan Otoritas Jasa Keuangan. Pandemi Covid19 yang terjadi saat ini sangat berpengaruh pada keberlanjutan dan inklusifitas keuangan UMKM yang diakibatkan oleh pembatasan sosial berskala besar (PSBB). Dampak yang ditimbulkan adalah terbatasnya gerak manusia dalam satu wilayah khususnya UMKM dalam menjangkau fasilitas lembaga keuangan syari'ah. Financial Technology menjadi salah satu pilihan di masa pandemi covid19 akan tetapi Peraturan Otoritas Jasa Keuangan Nomor 77/POJK.01/2016 Tentang Layanan Pinjam Memimjam Uang Berbasis Teknologi Informasi belum mampu mengakomodir fintech syari'ah sebagai opsi pembiayaan syari'ah di masa pandemi covid19.
\end{abstract}

\section{ARTICLE INFO}

\author{
Kata Kunci: \\ Peran Lembaga \\ Pembiayaan Syari'ah; \\ UMKM; Pandemi \\ Covid19 \\ Cite this paper: \\ Misbahul Ilham, I. H., \\ 2020. Memahami Peran \\ Lembaga Pembiayaan \\ Syari'ah Dalam \\ Meningkatkan \\ Aksesibilitas Keuangan \\ Umkm Pada Masa \\ Pandemi Covid19. \\ Widya Yuridika: Jurnal \\ Hukum, 3(2).
}

\section{PENDAHULUAN}

Usaha Mikro Kecil Menengah (UMKM), merupakan salah satu pendorong penguatan serta pembangunan ekonomi dunia. Peran dan kontribusi UMKM cukup signifikan dalam perekonomian nasional terutama dalam penyerapan tenaga kerja hingga 77.678.498 ribu orang atau sebesar $96.77 \%$ dari total tenaga kerja yang mampu diserap oleh usaha kecil, menengah dan besar. Perkembangan UMKM tidak luput dari sejarah perekonomian Indonesia pada krisis tahun 1998. Dalam krisis ekonomi dan krisis global yang terjadi dimana banyak pelaku usaha yang berskala besar menghadapi stagnasi operasional usaha sebab memiliki ketergantungan terhadap bahan baku dari pasar global bahkan 
berhentinya aktifitas usaha. Namun, Sektor UMKM terbukti lebih tangguh dalam menghadapi krisis tersebut, karena pada saat terjadinya krisis global, Pelaku UMKM banyak menggunakan bahan produksi local sehingga tidak menimbulkan dampak serius akibat krisis ekonomi tersebut.

Sejatinya, UMKM telah berhasil menunjukkan eksistensi dan kontribusinya yang cukup signifikan terhadap penyerapan tenaga kerja hingga 77.678.498 ribu orang atau sebesar $96,77 \%$ dari total tenaga kerja yang dapat diserap oleh para pelaku usaha UMKM khususnya pengembangan pada kualitas produk hasil UMKM Pertanian. ${ }^{1}$ Berdasarkan hal tersebut, perkembangan UMKM tidak dapat dilepaskan dari sejarah perekonomian Indonesia pada krisis tahun 1998. Dalam krisis ekonomi dan krisis global yang terjadi dimana banyak pelaku usaha yang berskala besar menghadapi stagnasi operasional usaha sebab memiliki ketergantungan terhadap bahan baku dari pasar global bahkan berhentinya aktifitas usaha. Namun, Sektor UMKM terbukti lebih tangguh dalam menghadapi krisis tersebut, karena pada saat terjadinya krisis global, Pelaku UMKM banyak menggunakan bahan produksi lokal sehingga tidak menimbulkan dampak serius akibat krisis ekonomi tersebut. Sedangkan, Eksisteni UMKM Pasca Reformasi dalam perekonomian nasional mengalami peningkatan yang cukup signifikan dan mendominasi model usaha di Indonesia yang menunjukkan jumlah populasi UMKM pada tahun 2007 mencapai 49,8 juta unit usaha atau 99,99 \% terhadap total unit usaha di Indonesia(Data Badan Pusat Statistik). Pun demikian Kontribusi UMKM dalam pembentukan PDB (Produk Domestik Bruto) juga cukup signifikan, yakni jumlah PDB mencapaiRp. 3.957,4 triliun, dimana UMKM telah memberikan kontribusi sebesar Rp.2.121,3 triliun atau 53,6 persen dari total PDB. ${ }^{2}$

Melihat peningkatan yang signifikan tersebut, ditemukan sebuah fakta bahwa saat ini UMKM di masa pandemic covid 19 juga memiliki kendala yang cukup serius apabila tidak diselesaikan melalui penerapan kebijakan dan implementasinya. Sebab, hadirnya fenomena revolusi industri 4.0 serta terbatasnya ruang gerak manusia mengakibatkan beralihnya sistem perekonomian yang awalnya konvensional menjadi virtual. Pentingnya seluruh kebijakan maupun aturan yang mengikat tingkah laku manusia harus dihadapkan dengan perkembangan teknologi yang begitu pesat serta upaya menjaga keuangan di masa pandemic covid19 agar secara perekonomian dapat berjalan normal. Disamping itu, Bentuk persaingan usaha saat ini lebih menekankan terhadap inovasi berbasis IT/artificial intelegence/machine learning dan terlebih menggunakan market intelegence sebagai basis pengembangan usahanya.

Persaingan yang terjadi juga disebabkan oleh masuknya produk-produk luar negri yang menciptakan daya saing global serta menuntut adanya inovasi terhadap perkembangan UMKM. Salah satu permasalahan akut terjadi pada pengembangan UMKM adalah Iklim usaha yang sulit diperkirakan. Menurut Hasil Kajian tim Fakultas Ekonomi Universitas Sumatera Utara menunjukkan bahwasannya masalah modal atau pembiayaan UMKM menempati urutan utama dalam peningkatan kapasitas usaha kecil dan menengah. Artinya bahwa persoalan internal yang menjadi domain UMKM adalah lemahnya kemampuan SDM dan Permodalan. Apabila terdapat penguatan terhadap permodalan, maka masalah-masalah runtutan seperti bahan baku tenaga kerja, produksi, pemasaran

\footnotetext{
1 Sri Susilo, Y. Pertumbuhan Usaha Industri Kecil dan Menengah (IKM) dan Faktor-faktor yang Mempengaruhinya. Eksekutif, Vol.4, No.2, (2007). hlm.306-313

2 Asnur, Daniel, Penyusunan DSS Studi Kelayakan Ekonomi dan Finansial bagi UKM, Jurnal Pengkajian UKM dan Koperasi, Volume 4. (2009) Hlm.1-14.
} 
serta distribusi yang lain dapat teratasi secara seimbang. Sedangkan kebijakan dan program pemerintah dalam hal peningkatan tersebut tidak berjalan secara maksimal.

Hal ini cukup berasalan, produk UMKM sebagai aset bangsa perlu diperhatikan lebih oleh pemerintah dalam hal menampik seluruh hambatan dan tantangan yang dimiliki oleh UMKM antara lain bentuk permodalan yang seyogyanya akan dapat mengatasi segala runtutan persoalan yang sering dihadapi oleh para pelaku usaha UMKM terutama aksesibilitas pada masa pandemi covid19.

Penelitian ini menggunakan tipe penelitian normatif (normative legal research) yaitu penelitian yang difokuskan untuk menganalisis penerapan kaidah atau norma dalam hukum positif dan menjadikan kaidah-kaidah hukum abstrak sebagai ukuran kebenaran dalam dalam studi hukum. Pendekatan yang digunakan yaitu sosio-legal (socio-legal studies) merupakan upaya untuk lebih jauh menjajaki sekaligus mendalami suatu masalah dengan tidak mencukupkan pada kajian norma atau doktrin hokum yang terkait, melainkan melihat secara lengkap konteks norma dan pemberlakuannya. ${ }^{3}$ Selain itu juga diperlukan pendekatan konseptual (conseptual approach) yaitu beranjak dari pandangan dan doktrin yang berkembang di dalam ilmu hukum. Sedangkan sumber yang digunkan dalam artikel ilmiah ini terdiri dari sumber bahan hukum primer, bahan hukum sekunder, dan bahan non hukum. Sumber tersebut sesuai karena bahan hukum merupakan alat dalam penelitian yang digunakan untuk memecahkan isu hukum dan sekaligus memberikan perskripsi mengenai apa yang seharusnya diperlukan. ${ }^{4}$

Metode analisis bahan hukum yang penulis gunakan dalam penelitian ini adalah menggunakan analisis deduktif, yaitu cara melihat suatu permasalahan secara umum sampai dengan pada hal-hal yang besifat khusus untuk mencapai perskripsi atau maksud yang sebenarnya. Langkah selanjutnya yang digunakan dalam melakukan suatu penelitian hukum adalah :Megidentifikasi fakta hukum dan menimalisir hal-hal yang tidak relevan untuk menetapkan isu hukum yang hendak dipecahkan; Pengumpulan bahanbahan hukum dan bahan-bahan non hukum yang dipandang mempunyai relevansi; Melakukan telaah atas isu hukum yang diajukan berdasarkan bahan-bahan yang telah dikumpulkan; Menarik kesimpulan dalam bentuk argumentasi dan menjawab isu hukum; dan Memberikan preskripsi berdasarkan argumentasi yang telah dibangun di dalam kesimpulan.

\section{HASIL DAN PEMBAHASAN}

\section{Model Pembiayaan Umkm Oleh Lembaga Pembiayaan Umkm (Tinjauan Yuridis Terhadap Peraturan Otoritas Jasa Keuangan Nomor 31/P.0jk.05/2014 Tentang Penyelenggaraan Usaha Pembiayaan Syari'ah)}

Secara klasik persoalan yang terjadi khususnya usaha mikro adalah rendahnya akses terhadap lembaga pembiayaan. Hal ini senada dengan data Bank Indonesia yang menunjukkan bahwa ditinjau dari sisi pembiayaan, banyak pelaku UMKM yang mengalami kesulitan untuk mendapatkan akses kredit dari bank, baik karena kendala teknis, misalnya keterbatasan akses perbankan dan lembaga pembiayaan yang tidak inklusif.Pemerintah melalui kebijakan dan programnya telah berupaya untuk meningkatkan pelayanan terhadap UMKM, Diantaranya melalui program, Saving Led Microfance, Credit Led Microfinance, Microbanking, Linkage Modal. Dengan model layanan diatas bahwa Pertanian, Perburuan dan Kehutanan dalam Hal Kredit dan Non Performing

\footnotetext{
${ }^{3}$ Muhammad Helmy Hakim, “Pergeseran Orientasi Penelitian Hukumm ; Dari Doktrinal ke Sosio-Legal," N.D ${ }^{4}$ Muhammad Abdulkadir, Hukum Dan Penelitian Hukum (Bandung: Citra Aditya Bakti, 2004).
} 
Loan terhadap UMKM yang memiliki pertumbuhan rata-rata 33.13 persen pada tahun 2017. Sementara itu, distribusi UMKM memiliki kendala untuk mendapatkan kredit adalah : prosedur pengajuan yang sulit $30,3 \%$, tidak berminat 25,34 persen, tidak memiliki agunan 19,28 persen, tidak mengetahui prosedurnya 14,33 persen, suku bunga tinggi 8,82 persen dan proposal ditolak 1,93 persen. Demikian bahwa seluruh persoalan yang terjadi mengarah pada layanan yang dimiliki oleh bank atau lembaga pembiayaan non bank konvensional. 5

Nugroho menjelaskan bahwa Inklusifitas keuangan bukan merupakan suatu hal yang utama dalam memecahkan problema kemiskinan dan ketimpangan, apabila aksesibilitas keuangan tidak mampu memperkuat sinergi antara perbankan dan LKM dalam sprektum ekosistem keuangan yang seharusnya lebih mudah di akses oleh pelaku UMKM. ${ }^{6}$ Selanjutnya penting bagi para perusahaan lembaga pembiayaan untuk bersinergi memperkuat keuangan pasar mikro yang kondusif bagi upaya peningkatan kewirausahaan masyarakat sehingga dapat mengaktualisasikan endowmen menjadi investasi produktif. Demikian halnya dengan program KUR dapat dikatakan cukup relatif berjalan dengan baik, namun distribusi KUR tersebut masih terjadi ketimpangan baik secara geografis maupun sektoral. ${ }^{7}$

Persoalan diskursus mengenai Implementasi Financial Technology dalam meningkatkan keuangan inklusif pada UMKM disebabkan tidak komprehesifnya regulasi dalam mengakomodir hadirnya inovasi teknologi baru dalam aktivitas perekonomian di Indonesia. Salah satunya disparitas regulasi yang dikeluarakan oleh OJK dalam bentuk Peraturan Otoritas Jasa Keuangan Nomor 77/P0JK.01/2016 ${ }^{8}$ Tentang Layanan Pinjam Memimjam Uang Berbasis Teknologi Informasi. OJK sebagai Regulator terkait jasa keuangan belum mengakomodir kebutuhan umat Islam dalam menggunakan layanan fintech berbasis syari'ah. Untuk sementara, industri fintech syari'ah berpedoman pada prinsip umum yang dikeluarkan oleh Dewan Syari'ah Nasional MUI dan peraturan perundang-undangan yang terkait dengan layanan keuangan berbasis teknologi Informasi. Hadirnya regulasi terkait fintech syari'ah ini diharapkan meningkatkan intensitas dan minat masyarakat dalam kesejahteraan ekonomi dan kepastian hukum.

Keterlibatan 0JK dalam mengatur regulasi terkait jasa keuangan juga tidak lepas dari peran Bank Indonesia yang juga memiliki kewenangan sebagai regulator dalam kapasitasnya yang telah di tentukan oleh peraturan perundang-undangan. Peraturan Bank Indonesia nomer 19/12/PB/2017 tentang penyelenggaraan financial technologi (PBI Tekfin) diterbitkan dengan pertimbangan sebagai berikut:

a) Perkembangan teknologi dan sistem informasi terus melahirkan berbagai inovasi yang berkaitan dengan teknologi finansial

\footnotetext{
5 Kementrian Koordinator Bidang Kesra RI, Program Pengembangan Keuangan Mikro Di Indonesia, Informasi Umum: Jakarta.

${ }^{6}$ Nugroho, A.E, Politik Ekonomi Kredit Program Untuk Pemberdayaan Usaha Mikro Kecil Menengah : Dari Bimas Hingga Kredit Usaha Rakyat, Bab V dalam buku Saptia, Yeni dan Nugroho,A,E 2017, Penguatan Peran Program Kredit Mikro dalam Mendorong Pengembangan UMKM Di Sektor Pertanian, Jakarta : LIPI -Press. ${ }_{77}$ Distribusi KUR terpusat di Jawa yakni sekitar 54\% dan sektor perdagangan mencapai 57,6\% dari total KUR. Selain itu, KUR tersebut cenderung tidak tepat sasaran pada masyarakat miskin yang mencoba mengakses kredit tersebut dalam peningkatan usahanya. Hal ini disebabkan desain program tersebut tidak secara spesifik ditujukan untuk RTM dengan tingkat risiko yang tinggi yang menyebabkan kengganan bank dalam melaksanakan penyaluran KUR terhadap RTM.

${ }_{8}$ Peraturan Otoritas Jasa Keuangan Nomor 77/P0JK.01/2016 Tentang Layanan Pinjam Memimjam Uang Berbasis Teknologi Informasi
} 
b) Perkembangan teknologi finansial disatu sisi membawa manfaat namundisisi lain memiliki potensi resiko

c) Ekosistem teknologi finansial perlu terus di monitor dan dikembang kan untuk mendukung terciptanya stabilitas moneter, stabilitas sistem keuangan, serta sistem pembayaran yang efisien, lancar, aman dan andal untuk mendukung pertumbuhan ekonomi nasional yang berkelanjutan dan inklusif

d) Penyelenggaraan teknologi finansial harus menerapkan prinsip perlindungan konsumen serta manajemen resiko dan kehati-hatian.

e) Respons kebijakan bank indonesia terhadap perkembangan teknlogi finansial harus tetap sinkron, harmonis dan terintegrasi dengan kebijakan lainnya yang dikeluarkan oleh bank indonesia

Ketentuan dalam peraturan Bank Indonesia ini berlaku pada penyelenggara teknologi finansial yang menyelenggarakan teknologi finansial di sistem pembayaran. ${ }^{9}$ Keberadaan suatu regulasi jika sudah dibuat adalah bagaimana implementasi aturan tersebut sejalan dengan faktor pendukung seperti infrastruktur. Pada saat ini infrastruktur IT yang baik hanya dapat dirasakan oleh masyarakat di perkotaan besar saja seperti Jakarta, Surabaya, Bandung dan lain sebagainya. Sedangkan jaringan internet belum dapat tersebar secara merata masuk ke daerah pelosok, inilah salah satu kendala terbesar penyebaran fintech sehingga tidak optimalnya pengimplementasian fintech kepada seluruh masyarakat di Indonesia. Tidak hanya cukup pembangunan infrastruktur dalam mengoptimalkan fintech tersebut, dikarenakan dibutuhkannya kemampuan sumber daya manusia yang mumpuni. Terbatasnya kemampuan yang dimiliki masyarakat pedesaan dalam mengaplikasikan financial technologi di daerahnya, membuat penyebaran financial technologi menjadi terhambat. Kondisi ini membuat pemerintah sulit untuk mengembangkan fintech di daerah tersebut dikerenakan kurangnya tenaga kerja yang dapat menunjang keberlangsungan perekonomian modern. Seharusnya penyediaan sumber daya manusia (SDM).

Masyarakat di daerah pedesaan sebagian besar belum mengenal istilah financial technologi secara menyeluruh tentang bagaimana cara penggunaannya, apa saja manfaatanya, keuntungan dan tujuan yang dapat diperoleh dari penggunaannya dikerenakan kurangnya literasi pemerintah dalam menegenalkan sistem keuangan yang baik. Oleh karenanya, diperlukan langkah-langkah sosialisasi dan diskusi-diskusi melalui jejaring media sosial baik untuk mendapatkan perhatian masyarakat maupun sebagai upaya mencari masukan demi perbaikan system yang ada, akibat rendahnya pengetahuan literasi keuangan, membuat masyarakat tidak mempunyai perencanaan dalam pengelolahan keuangan yang baik.

Pada dasarnya financial technologi memberi banyak kemudahan pada msyarakat akan tetapi kemudahan ini mengandung berbagai resiko, salah satunya terbukanya peluang akan terjadinya cybercrime. Dunia cyber yang sangat canggih memudahkan para pembobol untuk dapat melacak transaksi keuangan, sedangkan keamanan di daerah terpencil belum mencapai titik aman yang sempurna. Perlindungan nasabah merupakan salah satu isu utama dalam pengembangan bisnis SP-Tekfin yang diatur dan diawasi oleh BI. BI telah menerbitkan PBI nomor 16/1/PBI/2014 tentang Perlindungan Konsumen Penyelenggara Sistem Pembayaran yang mengatur perlindungan nasabah pengguna sistem pembayaran termasuk nasabah SP-Tekfin. Nasabah pengguna SP-Tekfin harus dilindungi agar dananya tidak hilang dibawa kabur penyelenggara. Sengketa perdata yang

\footnotetext{
9 Peraturan Bank Indonesia nomer 19/12/PB/2017 tentang penyelenggaraan financial technologi (PBI Tekfin)
} 
terjadi antara nasabah dengan pelaku usaha SP-Tekfin juga harus dapat diselesaikan secara cepat dan mudah melalui Alternatif Penyelesaian Sengketa (APS). Bisnis SP-Tekfin di Indonesia saat ini diatur dalam PBI18/40/PBI/2016 tentang Penyelenggaraan Pemrosesan Transaksi Pembayaran. Pihak yang ingin menjadi Penyelenggara Jasa Sistem Pembayaran (PJSP) untuk pertama kali harus lebih dulu mendapatkan "izin" dari BI. Pihak yang sudah memiliki ijin PJSP dan ingin melakukan pengembangan bisnis harus mendapatkan "persetujuan" dari BI. Pengembangan bisnis PJSP tersebut dapat berupa pengembangan kegiatan jasa sistem pembayaran, pengembangan produk dan aktifitas jasa sistem pembayaran serta kerja sama dengan pihak lain.

Kegiatan bisnis online dan transaksi elektronik (termasuk SPTekfin) juga terkait dengan UU 8/ 1999 tentang Perlindungan Konsumen. Masyarakat konsumen yang membeli produk atau melakukan transaksi pembayaran via internet harus mendapatkan perlindungan hukum agar mereka tidak dirugikan oleh pelaku usaha. Masyarakat juga harus dilindungi dari praktik penipuan dan kejahatan yang marak terjadi dalam bisnis online dan transaksi elektronik. Tindak pidana penipuan yang terjadi dalam bisnis online dan transaksi elektronik perlu ditangani melalui penerapan pasal penipuan dalam Kitab Undang-Undang Hukum Pidana (KUHP). Dalam penanganan tindak pidana penipuan, pihak konsumen dapat melaporkan kepada Kepolisian, sedangkan penyelesaian sengketa konsumen dengan pelaku usaha dapat diselesaikan melalui Badan Penyelesaian Sengketa Konsumen (BPSK).

Kegiatan bisnis melalui teknologi informasi baik e-commerce ataupun financial technology juga perlu diperhatikan dengan adanya UU Nomor 8 Tahun 2011 Tentang Informasi dan Transanksi Elektronik. Setiap industri yang menggunakan basis teknologi informasi dalam memasarkan produknya harus memenuhi informasi lengkat terkait mekanisme kontrak, persyaratan serta himbauan terkait perlindungan hukum dan lain sebagainya. ${ }^{10}$ Perlindungan terkait Fintech juga diatur mengenai aktivitas sebagai pelaku usaha dalam Peraturan Pemerintah nomor 82 Tahun 2012 Tentang penyelenggaraan sistem dan Transanksi elektronik. Dan diatur secara lebih khusus terkait layanan pinjam meminjam berbasis teknologi informasi dalam Peraturan Otoritas Jasa Keuangan / 77/P.0JK/01/2016.

Namun saat ini belum ada institusi yang dapat menangani masalah perangkat keamanan di Indonesia. Penempatan dana pada perusahaan teknologi keuangan atau financial teknologi pinjamaan (peer to peer lending) memiliki resiko yang tinggi. Hal ini, antara lain terlihat dari pembiayaan macet yang dengan cepat merangkak naik 1.,28 \% pada januari lalu. ${ }^{11}$ berdasarkan data 0JK rasio pinjaman macet pada perusahaan fintech tercatat berada di kisaran $1.28 \%$ pada akhir januari lalu. Kendati masih kecil, angka tersebut naik cukup signifikan disbanding posisi desember 2017 laluyang hanya sebesar 0.99\% padahal, penyaluran pinjaman fintech pada peroiode yang sama kian besar. Masih berdasarkan catatan OJK, pinjaman yang disalurkan Fintech mencapai Rp.3 trilliun. Naik signifikan dari Desember 2017 dikisaran Rp. 2.5 trilliun. dengan demikian, pinjaman

\footnotetext{
10 Di dalam UU ITE dijelaskan bahwa pelaku usaha harus menyampaikan informasi yang baik dan benar meliputi; informasi yang memuat identitas serta status subjek hukum dan kompetensinya, baik sebagai produsen, pemasok, penyelenggara maupun perantara; b. informasi lain yang menjelaskan hal tertentu yang menjadi syarat sahnya perjanjian serta menjelaskan barang dan/atau jasa yang ditawarkan, seperti nama, alamat, dan deskripsi barang/jasa.

11Kontan.co,id, 2018, Januari 2018, Kredit Macet Fintech Peer To Peer Lending Naik 1,28\%., https://keuangan.kontan.co.id/news/januari-2018-kredit-macet-fintech-lending-naik-jadi-128.
} 
macer fintech secara nominal, naik 54\% dari sekitar Rp. 2.5 milliar menjadi sekitar Rp.3.8 milliar. ${ }^{12}$

Oleh sebab itu, lembaga pembiayaan perlu beradaptasi secara serius dengan hadirnya industri teknologi finansial. Industri teknologi finansial (fintech) yang merupakan salah satu metode layanan jasa keuangan yang mulai populer di era digital sekarang ini. Pun demikian, pembayaran digital menjadi salah satu sektor dalam industri fintech yang paling berkembang di Indonesia. Sektor inilah yang kemudian paling diharapkan oleh pemerintah dan masyarakat untuk mendorong peningkatan jumlah masyarakat yang memiliki akses kepada layanan keuangan. ${ }^{13}$

Pemenuhan Aksesibilitas Pembiyaan Umkm Di Masa Pandemi Covid19 (Kajian Terhadap Peraturan Ototitas Jasa Keuangan Nomor 77/Pojk.01/2016 Tentang Layanan Pinjam Memimjam Uang Berbasis Teknologi Informasi)

Fintech berasal dari istilah Fintech berasal dari istilah financial technology atau teknologi finansial. Menurut The NationalDigital Research Centre (NDRC), di Dublin, Irlandia, mendefinisikanfintech sebagai " innovation infinancial services" atau "inovasidalam layanan keuangan fintech" yang merupakan suatu inovasi padasektor finansial yang mendapatsentuhan teknologi modern.Transaksi keuangan melaluifintech ini meliputipembayaran,investasi, peminjaman uang, transfer,rencana keuangan dan pembanding produk keuangan. Saat ini terdapat142 perusahaan yang bergerakdibidang fintech yang teridentifikasi. ${ }^{14}$

Industri financial technologi (fintech) merupakan salah satu metode layanan jasa keuangan yang mulai populer di era digital sekarang ini. Dan pembayaran digital menjadi salah satu sektor dalam industri FinTech yang paling berkembang di Indonesia. Sektor inilah yang kemudian paling diharapkan oleh pemerintah dan masyarakat untuk mendorong peningkatan jumlah masyarakat yang memiliki akses kepada layanan keuangan. ${ }^{15}$ Fintech dengan layanan keuangan seperti crowdfunding, mobile payments, dan jasa transfer uang menyebabkan revolusi dalam bisnis startup. Dengan crowdfunding, bisa memperoleh dana dari seluruh dunia dengan mudah, bahkan dari orang yang belum pernah ditemui sekalipun Fintech juga memungkinkan transfer uang secara global atau internasional. Jasa pembayaran seperti PayPal otomatis mengubah kurs mata uang, sehingga yang berada di Amerika bisa membeli barang dari Indonesia dengan mudahnya, Fintech juga memiliki peran penting dalam mengubah perilaku dan ekspektasi konsumen diantaranya :

a. dapat mengakses data dan informasi kapan saja dan dimana saja

b. Menyamaratakan bisnis besar dan kecil sehingga cenderung untuk memiliki ekspektasi tinggi meski terhadap bisnis kecil yang baru dibangun.

Secara global, Industri Fintech terus berkembang dengan pesat. Terbukti dari bermunculannya perusahaan startup di bidang pembiayaan serta besarnya investasi global di dalamnya. Khususnya di Indonesia, bisnis ini berkembang sangat pesat hingga menarik perhatian seluruh pebisnis di Indonesia. selain itu, terdapat hal yang perlu diperhatikan mengenai keuangan inklusif bagi kelompok in the bottom of pyramid ((pendapatan rendah yang tidak teratur, tinggal di daerah terpencil, orang cacat, buruh

\footnotetext{
12 Agustianti, Dikutip dari CNN.

${ }^{13}$ Budi Wibowo, Analisa Regulasi Fintech Dalam Membangun Perekonomian Di Indonesia, Jakarta, Indonesia

${ }^{14}$ Ernama Santi, Pengawasan Otoritas Jasa Keuangan Terhadap Financial Technology ( Peraturan Otoritas Jasa Keuangan Nomor 77/Pojk.01/2016, Diponegoro law journal, Volume 6, Nomor 3, Tahun 2017

15 Budi Wibowo, Analisa Regulasi Fintech dalam Membangun Perekonomian di Indonesia, Jakarta, Indonesia
} 
yang tidak mempunyai dokumen identitas legal, dan masyarakat pinggiran). Meskipun tergolong sebagai in the bottom of the pyramid serta tidak mempunyai tabungan (saving) dapat dipercaya antara mereka masih memiliki benda bergerak tidak produktif (holding) yang dipakai sehari-hari seperti cincin/kalung dsb yang dapat diuangkan dan dipergunakan untuk hal yang produktif seperti untuk modal usaha mikro non formal atau bercocok tanam dan beternak. Dengan menguangkan holding diharapkan bisa menjadi salah satu jalan menyelesaikan permasalahan dengan pembinaan yang dilakukan oleh lembaga pembiayaan. ${ }^{16}$

Bagi sebagian masyarakat mungkin hal ini merupakan sesuatu yang mustahil dilakukan. Memang membangun masyarakat kelas bawah (in the bottom of the pyramid) pada umumnya tidak semudah membangun kelas atas (middle and high income) yang mempunyai pandangan yang terbatas, sempit dan lepas dari pemikiran kehidupan masa depan serta suka melakukan jalan pintas. Dengan keadaan seperti ini perlu dibina karena pada dasarnya di dalam masyarakat ada kekuatan yang perlu diluruskan untuk kehidupan masa depan. Mental negatif seperti inilah yang perlu dilenyapkan dari diri mereka agar mereka bisa menjadi masyarakat mandiri sesuai kemampuan mereka. Financial inclusion (keuangan inklusif) didefinisikan sebagai upaya mengurangi segala bentuk hambatan yang bersifat harga maupun non harga, terhadap akses masyarakat dalam memanfaatkan layanan jasa keuangan. ${ }^{17}$

Keterlibatan persoalan diatas juga pada lembaga pembiayaan yaitu Perbankan konvensional dan syariah hadir sebagai wujud akses layanan pembiayaan melalui kredit dan pembiayaan berdasarkan prinsip-prinsip hukum islam. Hal ini berkaitan dengan Populasi umat islam di Indonesia yang mencapai sekitar $89,09 \%{ }^{18}$ menjadikan layanan keuangan berdasarkan hukum islam sebagai salah satu upaya menerapkan ajaran AlQur'an dan As-Sunnah sebagai landasan hukum dalam melakukan aktivitas ekonomi. Perbankan syariah sebagai salah satu lembaga keuangan intermediasi yang beroperasi berdasarkan prinsip syariah harus hadir untuk memenuhi kebutuhan-kebutuhan pelaku usaha.

Kebutuhan-kebutuhan tersebut tidak hanya dalam hal penyediaan modal, tetapi juga membantu dalam hal sistem pembayaran. Di era digital saat ini, bank syariah tidak boleh hanya melakukan kegiatan operasionalnya secara konvensional saja, yaitu hanya mengandalkan aktivitas lewat kantor-kantor cabang, yang cenderung bersifat esklusif. Akan tetapai, bank syariah harus melakukan inovasi dalam aktivitas bisnisnya, salah satu yang dapat dilakukan yaitu dengan melakukan kerjasama dengan perusahaan fintech. Sehingga, dengan melakukan kerjasama dengan perusahaan fintech, maka produkproduk yang ditawarkan oleh perbankan syariah akan dapat di akses oleh semua pelaku bisnis di seluruh wilayah Indonesia.

Untuk sementara, industri fintech syari'ah berpedoman pada prinsip umum yang dikeluarkan oleh Dewan Syari'ah Nasional MUI dan peraturan perundang-undangan yang terkait dengan layanan keuangan berbasis teknologi Informasi. Hadirnya regulasi terkait fintech syari'ah ini diharapkan meningkatkan intensitas dan minat masyarakat dalam kesejahteraan ekonomi dan kepastian hukum. Keterlibatan OJK dalam mengatur regulasi

\footnotetext{
${ }^{16}$ Bahctiar Hassan Miraza, Membangun Keuangan InklusifVol. 23, no 2 (2014). , Jurnal Ekonomi Manajemen dan Akuntansi,

17 Halim Alamsyah, (2016). "Pentingnya Keuangan Inklusif dalam Meningkatkan Akses Masyarakat dan UMKM terhadap Fasilitas Jasa Keuangan Syariah".

18 Mutawakkil, Politik Umat Islam Di Indonesia : Upaya Depotilisasi Pasca Kemerdekaan. (2009) Jurnal hunafa Volume 6 no. 2, Universitas Tadulako.
} 
terkait jasa keuangan juga tidak lepas dari peran Bank Indonesia yang juga memiliki kewenangan sebagai regulator dalam kapasitasnya yang telah di tentukan oleh peraturan perundang-undangan

Sebagai wujud konkrit adanya keterlibatan beberapa pihak dalam peranannya masing-masing untuk meningkatkan keuangan inklusif UMKM serta dapat menampung inovasi terhadap dunia financial technology. Dibutuhkannya suatu rekronstruksi terhadap pola pembiayaan terhadap UMKM melalui beberapa perubahan mekanisme, sistem serta regulasi yang tepat agar supaya dapat mengimbangi ketertinggalan secara hukum. Terbukanya dunia teknologi dan masifnya terjadi pencurian data melalui internet juga harus disikapi secara serius oleh industry fintech. Sebenarnya Big data dan Hukum hadir dalam menyikapi perkembangan teknologi melalui beberapa batasan-batasan terkait penggunaan data, perlindungan data pribadi dan perlindungan konsumen di dunia maya. Namun Indonesia belum mengatur secara detail atas big data dan memiliki pemisahan - pemisahan terkait masalah-masalah seperti perlindungan data pribadi dan lain-lain. Pesatnya financial technology diperkirakan juga akan mempengaruhi perkembangan bisnis pembiayaan konvensional terutama BPR (Bank Perkreditan Rakyat).

OJK dan BI lebih kearah mendukung adanya perkembangan fintech, disebabkan potensi besar dalam memperkuat industri keuangan di Indonesia. Industri ini diharapkan mampu memperluas partisipasi masyarakat dalam menjalankan suatu usaha. ${ }^{19}$ Lembaga keuangan syari'ah memiliki potensi market dengan peluang bisnis yang menguntungkan bagi perbankan syari'ah, seperti International trade finance sindicated financing, Margin During Construction (MDC), hybrid take over dan refinancing, KPRS inden, pembiayaan reimbus, IMBT dan ijarah Maushifah fizzimmah, serta Musyarakah mutanaqishah, Akad Musyarakah Mutanaqishah dapat diterapkan dalam 11 produk dan kebutuhan bisnis nasabah.

Regulasi perbankan yang ada kiranya masih perlu disesuaikan agar memenuhi ketentuan syariah agar bank syariah dapat beroperasi secara relatif dan efisien serta mampu bersaing, antara lain; pertama, instrument yang diperlukan untuk mengatasi masalah likuiditas; kedua, instrument moneter yang sesuai dengan prinsip syariah untuk keperluan pelaksanaan tugas bank sentral; ketiga, standarisasi akuntansi, audit dan sistem pelaporan; keempat, regulasi yang mengatur mengenai prinsip kehati-hatian. Ketentuan keempat regulasi ini diperlukan agar bank syariah dapat menjadi elemen terpenting dari sistem moneter yang dapat menjalankan fungsinya secara baik, mampu berkembang dan bersaing. ${ }^{20}$

Sebagai wujud konkrit adanya keterlibatan beberapa pihak dalam peranannya masing-masing untuk meningkatkan keuangan inklusif UMKM serta dapat menampung inovasi terhadap dunia financial technology. Dibutuhkannya suatu rekronstruksi terhadap pola pembiayaan terhadap UMKM melalui beberapa perubahan mekanisme, sistem serta regulasi yang tepat agar supaya dapat mengimbangi ketertinggalan secara hukum. Terbukanya dunia teknologi dan masifnya terjadi pencurian data melalui internet juga harus disikapi secara serius oleh industry fintech. Sebenarnya Big data dan Hukum hadir dalam menyikapi perkembangan teknologi melalui beberapa batasan-batasan terkait penggunaan data, perlindungan data pribadi dan perlindungan konsumen di dunia

${ }^{19}$ Cita Yustisia dan Iswi Hariyani, 2017, Perlindungan Hukum Dan Penyelesaian Sengketa Bisnis Sistem Pembayaran Berbasis Teknologi Financial. Buletin Hukum Kebanksentralan, Volume 14 no 1.

${ }^{20}$ Gemala Dewi, Aspek-aspek Hukum dalam Perbankan dan Pereansuransian Syariah di Indonesia, Kecana Prenada Media Group, Jakarta, hlm.180. 
maya. Namun Indonesia belum mengatur secara detail atas big data dan memiliki pemisahan - pemisahan terkait masalah-masalah seperti perlindungan data pribadi dan lain-lain. Pesatnya financial technology diperkirakan juga akan mempengaruhi perkembangan bisnis pembiayaan konvensional terutama BPR (Bank Perkreditan Rakyat). Namun Sikap OJK dan BI lebih kearah mendukung adanya perkembangan fintech, disebabkan potensi besar dalam memperkuat industri keuangan di Indonesia. Industri ini diharapkan mampu memperluas partisipasi masyarakat dalam menjalankan suatu usaha. ${ }^{21}$

Keterlibatan masyarakat atau pengguna juga harus ada payung hukum dalam melindungi segala aktivitas yang dilakukan baik oleh penggunan jasa dan pemberi donator melalui jasa tersebut. Pengaturan terkait layanan pinjam meminjam atau profit sharing berbasis teknologi belum diatur langsung dalam peraturan ototitas jasa keuangan seperti pada P.0JK/77/2016 dimana dalam peraturan tersebut hanya mengatur terkait layanan konvensional sehingga belum secara penuh dapat memberikan kepastian hukum terhadap masyarkat. Padahal perkembangan terkait fintech syari'ah telah berkembang pesat di Indonesia.

Demi menjaga keamanan, penetapan syarat pemilikan modal yang cukuptinggi (di atasRp 20 miliar) menjadi penting sebagai mekanisme seleksi sekaligus quality control usaha karena P2P Lending adalah platform yang bersifat capital intensive dan sekaligus scalable. Peneliti Eksekutif Senior Departemen Pengembangan KebijakanStrategis OJK, Dr. HendrikusPassagi, kerap menekankan bahwa penyelenggara layanan ini perlu memiliki kapasitas dan kepiawaian dalam memitigasi risiko demi perlindungan konsumen serta untuk membela kepentingan nasional.

Perusahaan P2P Lending wajib memastikan keamanan dana publik, keamanan data publik, dan menjaga kesehatan serta kemampuan keuangan masyarakat khususnya dengan memberikan suku bunga yang wajar. Sementara dalam aspek perlindungan kepentingan nasional, perusahaan $P 2 P$ Lending harus dapat mencegah risiko pencucian uang, pembiayaan terorisme, dan mengantisipasi gangguan stabilitas sistem keuangan.. Namun meliha tperusahaan P2P lending yang masih menggunakan sistem konvensional dan menggunakan bunga (riba) terhadap peminjaman pembiayaan yang tentu bertentangan dengan hukum islam sehingga dibutuhkannya rekronstruksi pembiayaan UMKM dengan tetapmempertahankan hokum islam sebagai batas dalam operasionalny amaka seharusnya dibentuk $P 2 P$ lending berbasis ekonomi ummat dan ekonomi pancasila. Meski P2P Lending Syari'ah merupakan 'platform baru' dalam layanan keuangan fintech dan pertumbuhannya juga perlu didukung berbagai kebijakan baru, namun layanan ini diyakini akan berkembang secara progresif dan dapat menjadi bagian dari solusi untuk meningkatkan keuangan inklusif UMKM di Indonesia.

Layanan keuangan seperti $P 2 P$ Lending sangat relevan dan menjadi angin segar bagi Indonesia yang masih bekerja keras menyelesaikan sejumlah pekerjaan rumah; pertama, Indonesia masih perlu meningkatkan taraf inklusi keuangan masyarakatnya. Asosiasi FinTech Indonesia melaporkan masih ada 49 juta UKM yang belum bankable di Indonesia yang umumnya disebabkan karena pinjaman modal usaha mensyaratkan adanya agunan. P2P Lending dapat menjembatani UKM peminjam yang layak/credit worthy menjadi bankable dengan menyediakan pinjaman tanpa agunan. ${ }^{22}$ Meski memiliki potensi yang

\footnotetext{
21 Cita Yustisia dan Iswi Hariyani, 2017, Perlindungan Hukum Dan Penyelesaian Sengketa Bisnis Sistem Pembayaran Berbasis Teknologi Financial. Buletin Hukum Kebanksentralan, Volume 14 no 1.,hlm.12.

22 Heryucha Romanna Tampubolon,2019, Seluk-Beluk Peer To Peer Lending Sebagai Wujud Baru Keuangan Di Indonesia, Jurnal Bina Mulia Hukum, Volume 3 Nomor 2, hlm.
} 
besar, $P 2 P$ Lending juga perlu diatur secarahati-hati. Peran regulator sangat dibutuhkan untuk mendorong ekosistem usaha yang sehat. Perlu kebijakan yang lebih matang terkait syarat-syarat pendirian dan operasi fintech, proses penciptaan inovasi layanan yang aman bagi nasabah, dan penciptaan kompetisi yang sehat.

Lembaga keuangan syari'ah memiliki potensi market dengan peluang bisnis yang menguntungkan bagi perbankan syari'ah, seperti International trade finance sindicated financing, Margin During Construction (MDC), hybrid take over dan refinancing, KPRS inden, pembiayaan reimbus, IMBT dan ijarah Maushifah fizzimmah, serta Musyarakah mutanaqishah, Akad Musyarakah Mutanaqishah dapat diterapkan dalam 11 produk dan kebutuhan bisnis nasabah. ${ }^{23} \mathrm{Hal}$ inimenunjukkan bahwasannya market fintech syari'ah (khususnya payment dan lending syari'ah) di Indonesia sangat potensial dengan melihat mayoritas penduduk Indonesia yang $88,8 \%$ adalah muslim dan sebanyak $64 \%$ masih unbanked sebagai peluang besar dapat di implementasikan bisnis keuangan syari'ah.

Seperti telah diketahui fungsi umum daripada undang-undang melayani masyarakat dan memenuhi kebutuhan-kebutuhan masyarakat, sebagai azaz berlakunya dalam arti material, undang-undang merupakan sarana semaksimal mungkin dapat mencapai kesejahteraan spiritual dan material bagi masyarakat maupun individu.6 Regulasi perbankan yang berlaku belum sepenuhnya mengakomodir operasional bank syariah, mengingat adanya sejumlah perbedaan dalam pelaksanaan operasional bank syariah dengan bank konvensional. ${ }^{24}$

Regulasi perbankan yang ada kiranya masih perlu disesuaikan agar memenuhi ketentuan syariah agar bank syariah dapat beroperasi secara relatif dan efisien serta mampu bersaing, antara lain; pertama, instrument yang diperlukan untuk mengatasi masalah likuiditas; kedua, instrument moneter yang sesuai dengan prinsip syariah untuk keperluan pelaksanaan tugas bank sentral; ketiga, standarisasi akuntansi, audit dan sistem pelaporan; keempat, regulasi yang mengatur mengenai prinsip kehati-hatian. Ketentuan keempat regulasi ini diperlukan agar bank syariah dapat menjadi elemen terpenting dari sistem moneter yang dapat menjalankan fungsinya secara baik, mampu berkembang dan bersaing. ${ }^{25}$

\section{PENUTUP}

Problematika Pembiayaan UMKM melalui Lembaga Keuangan Syari'ah di Masa Pandemi Covid19 yaitu Pada penetapan harga produk pembiayaan oleh LKS yang kadang lebih tinggi dari bank konvensional juga mempunyai pengaruh pada kurangnya minat masyarakat dalam mengakses produk pembiayaan LKS, karena harga tersebut relatif cukup tinggi bagi pelaku UMKM, apalagi yang memiliki pendapatan relatif kecil. Oleh karena itu maka perlu adanya solusi untuk mempermudah akses UMKM terhadap pembiayaan syari'ah. Selain itu kebutuhan konsumen terhadap suatu inovasi layanan

\footnotetext{
${ }^{23}$ Hani Wardi Apriyianti,2017, Perkembangan Industri Perbankan Syariah Di Indonesia : Analisis Peluang Dan Tantangan,Jurnal Maksimum, Volume 1, No. 1, hlm.23.

24 Lihat Adiwarman A. Karim, hlm. 231-236, cakupannya; Konsep modal kerja mencakup modal kerja (working capital asset) dan modal kerja brutto (gross working capital, pengelolaan modal kerja (permanen dan seasonal, dan unsure-unsur modal kerja permanen (kas, piutang dagang dan persedian, serta perputaran modal dan alokasi dana

25 Gemala Dewi, Aspek-aspek Hukum dalam Perbankan dan Pereansuransian Syariah di Indonesia, Kecana Prenada Media Group, Jakarta, hlm.180.
} 
yang halal, aman, efisien dan inklusif merupakan pekerjaan besar bagi eksistensi LKS di era globalisasi.

Rekronstruksi Pembiayaan UMKM dilakukan terhadap perlindungan UMKM dan Lembaga Pembiayaan Syari'ah dengan mengintegrasikan peraturan-peraturan terkait layanan berbasis teknologi informasi; Undang-Undang UMKM, P.OJK dan BI sebagai regulator dan kontrol terhadap sistem pembayaran dan pengaliran dana terkait fintech. Rekronstruksi kedua yaitu dengan menghadirkan mekanisme layanan digital syari'ah sebagai penghubung antara lander dan borrower melalui kerjasama antara Industri Fintech Syari'ah lain, e-commerce, Perbankan Syari'ah dan Lander yang nantinya sebagai lander tetap dalam pengembangan UMKM. Strategi mengatasi risiko, fintech hasil kerjasama menciptakan peran putra daerah sebagai legitimator dan kontrol terhadap UMKM yang terkualifikasi bekerjasama dengan lander.

\section{Saran}

Rekronstruksi Pembiayaan UMKM dilakukan dengan penerapan etika pembiayaan syariah dalam P.OJK N0.31/P.0JK.5/2014 dimana hal tersebut sangat berpengaruh dalam pengoptimalkan penyelenggaraan pembiayaan syariah di Indonesia. Selain itu dibutuhkannya pembinaan dan pengawasan terhadap LKS yang memiliki produk pembiayaan syariah baru agar supaya dapat benar-benar terlaksananya prinsip dan etika pembiayaan syariah. Masa Pandemi Covid19, UMKM menantikan adanya kebijakan pemerintah yang inklusif dalam memanfaatkan financial technology syariah sebagai penyalur dana pinjaman UMKM.

\section{DAFTAR PUSTAKA}

\section{Buku/Jurnal/Dokumen}

Akifa P. Nayla, 2014, Komplet Akuntansi untuk UKM dan Waralaba, Laksana, Jogjakarta, 2014.

Asnur, Daniel, 2009, Penyusunan DSS Studi Kelayakan Ekonomi dan Finansial bagi UKM, Jurnal Pengkajian UKM dan Koperasi, Volume 4.

Budi Wibowo, Analisa Regulasi Fintech Dalam Membangun Perekonomian Di Indonesia, Jakarta, Indonesia

Bahctiar Hassan Miraza, (2014). Membangun Keuangan Inklusif, Jurnal Ekonomi Manajemen dan Akuntansi, vol. 23, no 2.

Halim Alamsyah, (2016). "Pentingnya Keuangan Inklusif dalam Meningkatkan Akses Masyarakat dan UMKM terhadap Fasilitas Jasa Keuangan Syariah".

Hani Wardi Apriyianti,2017, Perkembangan Industri Perbankan Syariah Di Indonesia: Analisis Peluang Dan Tantangan,Jurnal Maksimum, Volume 1, No. 1

Irma Mudzalifa, dkk, 2018, Peran Fintech dalam meningkatkan keuangan inklusif pada UMKM di Indonesia, Jurnal Masharif Asyari'ah Volume 3 Nomor 1, Universitas Muhammadiyah Surabaya.

Mutawakkil,2009, Politik Umat Islam Di Indonesia : Upaya Depotilisasi Pasca Kemerdekaan. Jurnal hunafa Volume 6 no. 2, Universitas Tadulako.

Cita Yustisia dan Iswi Hariyani, 2017, Perlindungan Hukum Dan Penyelesaian Sengketa Bisnis Sistem Pembayaran Berbasis Teknologi Financial. Buletin Hukum Kebanksentralan, Volume 14 no 1.

Gemala Dewi, Aspek-aspek Hukum dalam Perbankan dan Pereansuransian Syariah di Indonesia, Kecana Prenada Media Group, Jakarta. 
Meilisa Salim et.al, (2014). Analisis Implementasi Program Financial Inclusion Di Wilayah Jakarta Barat Dan Jakarta Selatan (Studi pada Pedagang Golongan Mikro, Instansi Perbankan, Otoritas Jasa Keuangan dan Bank Indonesia), [Skripsi], Universitas Bina Nusantara.

Triana Fitriastuti, et. al, (2015). Implementasi Keuangan Inklusif Bagi Masyarakat Perbatasan (Studi Kasus Pada Kutai Timur, Kabupaten Kutai Kartanegara Dan Kota Samarinda, Kalimantan Timur, Indonesia).

Muhammad Abdulkadir, Hukum Dan Penelitian Hukum (Bandung: Citra Aditya Bakti, 2004)

Yusuf Qardhawi, 2014 Problematika Rekonstruksi Ushul Fiqih, (Tasikmalaya: Al-Fiqh AlIslâmî bayn Al-Ashâlah wa At-Tajdîd,).

Sri Susilo, Y. 2007, Pertumbuhan Usaha Industri Kecil dan Menengah (IKM) dan Faktorfaktor yang Mempengaruhinya. Eksekutif, Vol.4, No.2, hlm.306-313

Kementrian Koordinator Bidang Kesra RI, Program Pengembangan Keuangan Mikro Di Indonesia, Informasi Umum: Jakarta.

Nugroho, A.E, (2017). Politik Ekonomi Kredit Program Untuk Pemberdayaan Usaha Mikro Kecil Menengah : Dari Bimas Hingga Kredit Usaha Rakyat, Bab V dalam buku Saptia, Yeni dan Nugroho,A,E 2017, Penguatan Peran Program Kredit Mikro dalam Mendorong Pengembangan UMKM Di Sektor Pertanian, Jakarta : LIPI -Press.

Setyobudi, Andang. 2007. Peran Serta Bank Indonesia Dalam Pengembangan Usaha Mikro, Kecil dan Menengah (UMKM). Buletin Hukum Perbankan Dan Kebanksentralan. Volume 5, Nomor 2.

Winarni, Endang Sri. 2006. Strategi Pengembangan Usaha Kecil Melalui Peningkatan Aksesibilitas Kredit Perbankan. Diunduh pada tanggal 23 Oktober 2012.

Mutawakkil,2009, Politik Umat Islam di Indonesia : upaya depotilisasi pasca kemerdekaan. Jurnal hunafa Volume 6 no. 2, Universitas Tadulako.

Nofita Wulansari, Akselerasi Pertumbuhan Ekonomi Melalui Sinergi Umkm Dan Good Governance di Indonesia, Prosiding Seminar Nasional dan Call For Paper Ekonomi dan Bisnis (SNAPER-EBIS 2017) - Jember, 27-28 Oktober 2017 (hal 262-268) ISBN : 978-602-5617-01-0

\section{Peraturan Perundang-undangan}

Undang-Undang Nomor 20 Tahun 2008 Tentang Usaha Mikro, Kecil, dan Menengah

Undang-Undang Nomor 21 Tahun 2008 Perbankan Syari'ah

Peraturan Otoritas Jasa Keuangan Nomor 77/POJK.01/2016 Tentang Layanan Pinjam Memimjam Uang Berbasis Teknologi Informasi

Peraturan Presiden Republik Indonesia Nomor 9 Tahun 2009 Tentang Lembaga Pembiayaan

Peraturan Otoritas Jasa keuangan Nomor 31/P.0JK.05/2014 Tentang Penyelenggaraan Usaha Pembiayaan Syari'ah

DSN MUI Nomor 117/DSN-MUI/IX/2018 tentang Layanan Pembiayaan Berbasis Teknologi Informasi Berdasarkan Prinsip Syariah

\section{INTERNET}

Bps.co.id, 2018, Penduduk Indonesia Menurut Provinsi 1971,1980,1990,1995,2000, dan 2010, $\quad$ https://www.bps.go.id/statictable/2009/02/20/1267/pendudukindonesia-menurut-provinsi-1971-1980-1990-1995-2000-dan-2010.html. di akses pada tanggal 20 Juli 2018. 
Widya Yuridika: Jurnal Hukum, Volume 3 / Nomor 2 / Desember 2020

Kontan.co.id, 2018, Januari 2018, Kredit macet fintech peer to peer lending naik 1,28\%., https://keuangan.kontan.co.id/news/januari-2018-kredit-macet-fintechlending-naik-jadi-128. 